\title{
O EXERCÍCIO DA OBSERVAÇÃO NO ESTUDO DA PAISAGEM: REDUNDÂNCIAS E ESSENCIALIDADES
}

\author{
Maria Augusta Mudim Vargas \\ Universidade Federal de Sergipe, Programa de Pós-Graduação em Geografia, São Cristóvão, SE, Brasil \\ guta98@hotmail.com.br
}

\begin{abstract}
RESUMO
O texto evidencia a observação no estudo da paisagem e propõe ao leitor compartilhar questões a respeito de sua utilização como procedimento metodológico. Desenvolve-se expondo as "observações" nos caminhos metódicos - indutivos, dedutivos e dialéticos -, construídos pelos paradigmas que norteiam a produção geográfica. Para tal, toma um trabalho de campo como chão empírico, o que ocorreu no povoado Fazenda Velha, município de Sete Lagoas, no estado de Minas Gerais. Isso possibilitou expor redundâncias e essencialidades advindas das vivências e reflexões com a paisagem do lugar visitado. Ademais, as práticas e vivências com os participantes evidenciaram o êxito dos caminhos de nossas reflexões.
\end{abstract}

Palavras-chave: Pesquisa geográfica. Etnogeografia. Objetividades. Subjetividades.

\section{THE EXERCISE OF OBSERVATION IN LANDSCAPE STUDIES: REDUNDANCIES AND ESSENTIALITIES}

\begin{abstract}
This article addresses the role of observation in landscape studies and invites readers to consider its use as a methodological tool. The article centres on "observations" adopted by inductive, deductive and dialectic trends that have been established by research paradigms in Geography. To that end, it sets off from a fieldwork experience as an empirical, what happened in the village Fazenda Velha, municipality of Sete Lagoas, state of Minas Gerais. This made it possible to expose redundancies and essentialities arising from the experiences and reflections with the landscape of the place visited. In addition, the practices and experiences with the class showed the success of the paths of our reflections.
\end{abstract}

Keywords: Geographic research. Ethnogeography. Objectivities. Subjectivities

\section{INTRODUÇÃO}

Com este artigo tem-se a pretensão de refletir sobre o emprego da observação da paisagem, tomando a experiência ocorrida com a vivência com discentes durante a ministração de disciplinas, particularmente ao longo da realização de um trabalho de campo em Minas Gerais. ${ }^{1}$

Como expectativa, pretende-se compartilhar questões que possam ser de interesse, sobretudo, para aqueles que se debruçam em estudos no âmbito da Geografia Cultural orientados pelos caminhos etnogeográficos em que se impõe a descrição densa (CLAVAL, 2004, 2011), na vizinhança metódica dos caminhos indutivos, dedutivos e dialéticos construídos pelos paradigmas que norteiam a produção geográfica. É certo que a paisagem permanece suscitando reflexões advindas de sua natureza, seja

\footnotetext{
1 O trabalho de campo ocorreu como atividade da disciplina Instrumental e Técnicas em Pesquisa Qualitativa, ministrada em abril de 2019, no Instituto de Geociências da Universidade Federal de Minas Gerais (UFMG), no contexto do Projeto de Mobilidade Acadêmica, Edital n 10/2016 da Coordenação de Aperfeiçoamento de Pessoal de Nível Superior/Fundação de Apoio à Pesquisa e Inovação Tecnológica do Estado de Sergipe (Capes/Fapitec), com participação de discentes, mestrandos e doutorandos, oriundos da UFMG, da Universidade Federal de Viçosa (UFV), da Universidade Estadual do Norte de Minas (Unimontes) e da Universidade Federal de Uberlândia (UFU). A coordenadora do Projeto, Professora. Sonia Menezes, o coordenador da UFMG, Professor José Antônio de Deus, também participaram da atividade de campo e, como os discentes, estão cientes de que a experiência suscitou a reflexão sobre a observação e a elaboração deste texto.
}

Caminhos de Geografia $\quad$ Uberlândia-MG $\quad$ v. 21, n. $76 \quad$ Ago/2020 $\quad$ p. 98-115 Página 98


por sua inserção em diferentes postulados metodológicos, seja pela significância do olhar do geógrafo para a paisagem objeto, para a paisagem categoria e, ainda, pelos múltiplos ângulos de ver, ter e pertencer à paisagem, quer pelos percursos epistêmicos ou pelas travessias da vida.

As tarefas de ler e escrever sobre a paisagem consistem em embarcar em um jogo que ora expõe revelações, ora enigmas a serem desvelados, pois é inegável sua apreensão como imagem, como tudo que a visão alcança, o que percebemos com nossos sentidos - audição, olfato, tato e visão. Nessa trilha perceptiva e pela influência de Tuan (1980), Kozel (2012) traz como contribuição a geopoética das paisagens ao aproximar o olhar da audição e das sensações por diferentes formas, seja pelas artes visuais, música, odores, exposição oral e escrita, sinalizando-os como instrumentos de leitura da paisagem pela "alma do lugar". Por esses constituintes, diferentes pessoas enxergam diferentes paisagens, assim como diferentes métodos desvelam diferentes paisagens. Esse discernimento é apontado por Souza (2013, p. 48-49) ao sublinhar "o fato de ser uma forma, uma aparência, significa que é saudável 'desconfiar' da paisagem. É conveniente interpretá-la ou decodificá-la à luz das relações entre forma e conteúdo, aparência e essência".

Acrescenta-se, ao propor e planejar um trabalho de campo tomando a paisagem como categoria e a observação como procedimento, assumimos que pensamos de pronto no contexto epistemológico e somamos-lhe o grande prazer em observar. A observação como processo de descoberta, a despeito de "relegada e até malvista", proporciona "observar o papel da espacialidade" (GOMES, 2013, p. 16).

Há de se ressaltar a observação como técnica de pesquisa cujos pressupostos vão muito além de uma descrição, mesmo que minuciosa, dos componentes e características de uma dada paisagem ou fenômeno, pois permite identificar a orientação, a dinâmica e o sentido do que se observa. Como tal, amparamos o desenvolvimento do texto em vasta produção, com realce para Weber $(2000,2009)$, Witaker (2002), Turato (2005), Brandão (2006), Gil (2008), Marconi e Lakatos (2008) e Lakatos (2010).

É pois, nesse contexto, entre questões teóricas e metodológicas postas pelas abordagens que essencializam a paisagem, que são expostas as redundâncias e essencialidades da observação, no sentido de aguçar o interesse para essa técnica de pesquisa, estimular sua adoção e, sobretudo, fomentar uma discussão que possibilite seu uso sem "ranços" metódicos. O propósito de distinguir e destacar redundâncias e essencialidades revela nossa intenção didático-pedagógica, ao trazer diferentes visões da paisagem entrecruzando o olhar dos moradores do lugar Fazenda Velha ${ }^{2}$ com o olhar geográfico, evidenciando, assim, algumas possibilidades de enxergar a paisagem por distintas abordagens.

Com essas ressalvas, apresentamos as partes do texto. Além dessa introdução, desenvolvemos três outras partes. A primeira procura detalhar o percurso metodológico em uma síntese mesclada pela condução de conhecimentos e experiências na sala de aula, pela escuta de vivências exitosas e outras nem tanto. Como um diário, estão descritos os passos para a aproximação e prospecção do povoado Fazenda Velha, pela intenção de observá-lo com exposição de uma etnogeografia de percurso (PEIRANO, 2016), ancorada pelo roteiro de trabalho de campo produzido que abarcou diário de campo, entrevista, registro fotográfico e oficina.

A segunda releva a paisagem para além das inúmeras formas de interpretá-la e delimitá-la assinaladas na seção anterior, quais sejam, pela observação simples, sistemática, estruturada, participante em equipe, individual, intensiva; pela importância da observação na construção do diário de campo, na elaboração de entrevistas e na realização de oficinas. As fotos apresentadas foram registradas pelos pesquisadores e evidenciam a materialidade da paisagem e a subjetividade do pesquisador que vê, olha e enxerga pela "lente" de seus conhecimentos.

Em seguida é tecido um desfecho da experiência expondo alguns pontos que inquietaram e outros que permanecem suspensos, tanto quanto os que instigaram o aperfeiçoamento teórico-metodológico de alguns temas pelas práticas, vivências e sociabilidades oriundas de um breve convívio.

2 Povoado do município de Sete Lagoas distante seis quilômetros da sede e cinquenta quilômetros de Belo Horizonte, capital de Minas Gerais. Seus constitutivos são desvelados ao longo do texto. 


\section{FIXANDO O OLHAR: ORIENTAÇÕES SUBSTANTIVAS}

A observação como um procedimento de campo inclui as sensações vivenciadas e lembradas posteriormente, bem como o quanto ela é conduzida pelas escolhas de conceitos e metodologias, como, por exemplo, se qualitativas ou quantitativas, se por alinhamentos comparativos, correlacionais ou compreensivos. A observação e o diário, definidos como procedimentos do trabalho de campo, que motivou a escrita reflexiva desse texto, foram assertivos pelo fato de essencializarem a análise dos fenômenos e do lugar Fazenda Velha, mas, também, por proporcionarem uma autoanálise do que se observou.

Em resumo, realizou-se um levantamento prévio sobre a geografia do povoado Fazenda Velha, contando para isso também com a experiência de uma das discentes como professora da única escola municipal do lugar. A experiência do trabalho de campo, como impulsionadora das questões aqui tratadas, foi iniciada com um esboço da pesquisa, quando foram balizados os interesses e os limites metodológicos. Os temas de interesse apontados e definidos nesse momento estão expostos no Quadro 1, cujo arranjo temático explica e justifica a escolha da paisagem como categoria de análise.

Quadro 1 - Esboço da pesquisa.

\begin{tabular}{|c|c|c|c|c|}
\hline Interesses & Instrumentais & Campo & Análise & Categoria \\
\hline Espaço & \multirow{8}{*}{$\begin{array}{l}\text { Pré-campo: } \\
\text { levantamentos } \\
\text { documental, } \\
\text { cartográfico e } \\
\text { imagens }\end{array}$} & $\begin{array}{c}\text { Primeira } \\
\text { aproximação: } \\
\text { percurso rápido }\end{array}$ & Espacialidades & \multirow{8}{*}{$\begin{array}{c}\mathbf{P} \\
\mathrm{A} \\
\mathbf{I} \\
\mathrm{S} \\
\mathrm{A} \\
\mathrm{G} \\
\mathrm{E} \\
\mathrm{M}\end{array}$} \\
\hline Lugar & & & Representações & \\
\hline Religiosidade & & $\begin{array}{c}\text { Aproximação em } \\
\text { equipe }\end{array}$ & Referências & \\
\hline Gastronomia & & & Iconografia & \\
\hline Topônimos & & $\begin{array}{c}\text { Aproximação } \\
\text { individual }\end{array}$ & Toponímia & \\
\hline Ocupações & & (Registro & Topofilia/topofobia & \\
\hline Eventos/festas & & $\begin{array}{l}\text { fotográfico; } \\
\text { entrevistas: }\end{array}$ & Percepções & \\
\hline Percepção & & $\begin{array}{c}\text { estruturada, } \\
\text { informal; oficina) }\end{array}$ & & \\
\hline
\end{tabular}

De acordo com Weber (2000), há de se considerar as diferentes técnicas de observação - se sistemática, participante, por vivências - e, igualmente, as distintas formas e intenções de realização de diários de campo. Estes podem ser organizados por observações estruturadas orientadas pela etnografia, pelos conteúdos da pesquisa, por registros temporais ou até mesmo intuitivos do pesquisador. A realização célere do campo em apenas um dia afastou a necessidade de observações sistematizadas, todavia, elas estão coadunadas com a execução de uma "etnogeografia" de percurso. ${ }^{3}$ Weber (2009) pontua que o etnógrafo não é um sujeito unificado. Ele é essencialmente um compilador que recopia ou transcreve os dados que são fornecidos pela observação ou por entrevistas. ${ }^{4}$

Caso se considere que a observação finda no conhecimento do objeto - no caso a paisagem - e no reconhecimento de seus elementos, ela se posiciona no contexto da lógica formal clássica: o município de Sete Lagoas situa-se numa região cárstica e o povoado Fazenda Velha pertence a Sete Lagoas; logo, Fazenda Velha situa-se numa região cárstica. Ou pela dedução de que condomínios fechados foram implantados nas cercanias de Sete Lagoas após segunda metade da década de 1980 e que,

${ }^{3}$ Concordamos com Peirano (2016), ao afirmar que a etnografia transforma o ponto de vista teórico e, por extensão, que o percurso etnogeográfico pode desvelar analítica e criticamente o lugar Fazenda Velha.

${ }^{4} \mathrm{~A}$ esse respeito sugerimos os textos de Laplantine (2004) e Boin e Burigo (2018). 
como Fazenda Velha situa-se próximo à sede, possui condomínios. De fato, situa-se sobre relevo cárstico e foram identificados três condomínios na localidade.

Em face ao exposto, questiona-se: em que consiste a observação que se finda nessa lógica de exposição de apenas uma visão estática do espaço? Consiste em uma observação que pouco contribui e acrescenta ao conhecimento, pois o que se conclui, no caso a ocorrência do relevo cárstico e a existência de condomínios, já havia sido exposto nas premissas sobre Sete Lagoas e não possibilita uma compreensão contextual, tampouco de suas relações intercalares. Essas colocações levam a pontuar, pelo menos, dois aspectos decorrentes da necessária descrição como consequência da observação: sua construção com explicações causais e elaboradas, muitas vezes, tomando como referentes as narrativas do senso comum e do cotidiano das pessoas entrevistadas.

Com relação às explicações causais, é oportuno retomar a significativa obra de Pierre George (1972), que à época contribuiu de forma significativa para o adensamento da Geografia como disciplina. Em seu texto Os métodos da Geografia, o percurso metodológico do geógrafo inicia-se ao se deparar com a paisagem, "objeto essencial de curiosidade e do estudo geográficos". Diz George (1972, p. 22):

A paisagem é uma resultante de legados ou de forças atuais ou do passado as quais, em si mesmas, fogem ao domínio do visível: são elas tanto as longas sequências de acontecimentos geológicos ou históricos, como os fluxos de capitais ou as redes de comando e de decisão ligadas às estruturas.

Pierre George (1972) nos revela a observação específica do geógrafo que, ao se deparar com a paisagem, levanta/identifica problemas e se propõe explicá-los, comparando-os e classificando-os com o uso de instrumentos metodológicos próprios da Geografia e de outras ciências, estas, para ele, afeitas ao conhecimento do invisível, ou seja, do que não é do domínio da Geografia. O autor refere que, no domínio do visível, o geógrafo deve buscar visões de conjunto que "oferecem a explicação para as respectivas localizações e para os agrupamentos, fazendo com que surjam os sistemas fundamentais de relações" (GEORGE, 1972, p. 26).

É pontuado, assim, que a observação não deva ser relegada, ou até mesmo aprisionada, ao método positivista, demarcado, dentre outros encaminhamentos, pela abordagem causal. Considerando que a observação antecede a descrição, destacam-se os dois aspectos levantados.

O primeiro sinaliza que a observação se dá pelo conhecimento que temos do mundo, por nossas vivências e, nesse sentido, por ideias preconcebidas, por traduções e reavaliações. Para Merleau-Ponty (1999, p. 334), perceber envolve o conhecimento preconcebido que temos sobre o espaço para além da imagem que vemos; observar/perceber é, de certa forma, "sobreviver à subversão das aparências". Nessa perspectiva, acrescentamos à antecedência da descrição a nossa vivência no campo, seja pelas pré-noções do observador e de sua percepção dos elementos da paisagem, seja pela paisagem mesma de Fazenda Velha.

O segundo assinala que a descrição não se restringe, e não se finda, à exposição dos objetos - "o que e onde" - e tampouco a explicações de relações causais baseadas em teorias e modelos. Luís de Gusmão (2012) ainda aponta que a descrição também envolve princípios explicativos extraídos da observação e registros do cotidiano, o que, para ele, diz respeito a uma descrição "conteudística" que pode ser produzida de forma inteligente. Sobre isso, valendo-se da historiografia de Marx, ${ }^{5}$ Gusmão (2012) aborda acerca do fetichismo do conceito e tece críticas aos posicionamentos enclausurados das "igrejinhas teóricas". Ao discorrer sobre os extremos entre explicações teóricas e as análises embasadas no conhecimento de senso comum, destaca "a necessidade iniludível de investimentos cada vez maiores numa pesquisa empírica séria, exaustiva e, sobretudo, não tutelada por um pseudoconhecimento do geral [refere-se aos enunciados de teorias gerais], pesquisa esta que não se limite a ilustrar duvidosas verdades gerais" (GUSMÃO, 2012, p. 82).

Portanto, é válido atentar para a observação no processo de construção metodológica inserida para além do ato de registrar e descrever, associada ao bom senso e ao rigor empírico que considere as

${ }^{5}$ Refere-se à aplicação da dialética na interpretação da história, que Marx divide em seis fases, apoiado em uma teoria geral (GUSMAึ̃O, 2012). 
explicações causais "conteudísticas", como registra Gusmão (2012, p. 14): "que o particular ilumina o geral e não o inverso [...]; que não se contente com uma formulação abstrata, baseada em leis ou em mecanismos e modelos estruturais".

Denis Cosgrove (2012), certamente impulsionado pela observação, afirmou que "a Geografia está em toda parte" e que a paisagem resulta do modo como ela é vista. Seu olhar trouxe importante contribuição para a emergência da abordagem cultural na Geografia, ${ }^{6}$ pois qualificou a paisagem como uma tradução política e ideológica. Mediante sua visão de mundo e suas opções metodológicas, Cosgrove observa e interpreta as paisagens das classes dominantes; as paisagens alternativas emergentes que antecipam o futuro; as paisagens alternativas residuais que sobraram do passado; as paisagens excluídas que foram suprimidas de forma ativa ou passiva, dentre outras, e complementa: "[...] cada uma dessas subculturas encontra alguma expressão na paisagem [...] e todas as paisagens possuem significados simbólicos porque são produto da apropriação e da transformação do meio ambiente pelo homem" (COSGROVE, 2012, p. 228).

Com essas considerações, promove-se a observação como técnica comum aos interesses dos diversos caminhos metódicos da turma, pois "adequamos e alojamos" todos, ao não desviá-los do conhecimento prévio que têm de seus objetos de estudo. Desta feita, apresentamos a possibilidade de utilizar a observação como técnica conteudística, com bom senso e rigor empírico, enfim, com o olhar de um etnogeógrafo. Assim, construiu-se um roteiro de observação, norteador para a realização de diário, entrevista, registro fotográfico e oficina, com as seguintes partes constitutivas:

(i) Perfil: para o balizamento das entrevistas, solicitando o nome (opcional), a naturalidade, a idade e a linha do tempo do entrevistado quanto a suas ocupações e fazeres em Fazenda Velha;

(ii) Referências do lugar: para o registro da percepção do pesquisador no diário e nos registros fotográficos, considerando: a) a história do lugar; b) as referências simbólicas mais importantes; c) o de que mais gosta e/ou é mais importante; d) acontecimentos, fenômenos, festas etc.;

(iii) Percepções: para o registro dos sentimentos e dos significados do lugar Fazenda Velha, considerando: a) como se sente (percebe) morando no lugar; b) expressar, se caso mudar para outro lugar, o que levaria na "mala das lembranças"; c) expressar, se fosse um pintor, o que colocaria no desenho de Fazenda Velha; d) expressar o cotidiano do lugar - semana, meses, o ano, os marcos; e) se já foi entrevistado ou conhece alguém que já tenha sido sobre Fazenda Velha e opinião a respeito.

O roteiro expressa, com efeito, a busca de informações que possam responder aos desafios postos, quais sejam, o de empreender um exercício de percepção no sentido em que Merleau-Ponty (1999, p. 99) situa a experiência como ato que antecipa a filosofia, pois, para ele, "a filosofia nada mais é do que uma experiência elucidada". Aqui repousa a discussão sobre a subjetividade que permanece inacabada para uns, mas indiscutivelmente posta pela abordagem positivista que questiona até que ponto a percepção pode ser considerada como conhecimento cientificamente válido e fidedigno do fenômeno estudado.

Ademais, há o entendimento de que nem todas as representações podem ser explicadas objetivamente, pois se presentificam sensíveis à realidade externa e factual. Elas são apreendidas pela imagem visual, auditiva, tátil, olfativa, cinestésica, cenestésica, etc., como tratada pela geopoética de Salete Kosel (2012), que busca, pela autopoiesis, significados e inteirezas na análise da paisagem, pensando a natureza por meio do olhar, dos cheiros e dos sons.

Pela orientação compartilhada com os autores trabalhados, assumimos que a necessidade de registrar aguça a observação e a observação aguça a necessidade de registrar, descrever, comparar, relacionar. E para maior clareza sobre as conexões entre as aulas expositivas, a elaboração do roteiro de campo e observações feitas, apresentam-se a seguir, mesmo que sucintamente, as técnicas realizadas, ressaltando-as no contexto de seus usos em pesquisas qualitativas.

Com esse entendimento, o diário essencializa as relações nutridas entre o pesquisador e o objeto de estudo, isto é, ele expõe sua importância substantiva ao objetivar a posição do observador. Tal posição,

${ }^{6}$ A esse respeito ver também Claval (2011) e Pedrosa (2016).

Caminhos de Geografia Uberlândia-MG v. 21, n. 76

Caminhos de Geografia Uberlândia-MG V. 21, n. 76

Ago/2020

p. $98-115$

Página 102 
neste caso, é dada por nossa ancoragem geográfica na análise espacial delineada pela categoria paisagem. Embora objetive as posições do pesquisador, o diário não deve ser necessariamente (ou se exigir dele) um texto acadêmico no sentido do encadeamento de questões, objetivos, metodologia, resultados e conclusões. Parece uma ressalva óbvia, mas atenta-se que a descrição é posta como instrumento para o entendimento e compreensão, para apreensão e ordenamento, enfim, importante para o desenrolar da pesquisa.

Weber (2009) ressalta o tratamento diferenciado dado aos diários de campo de acordo com os métodos, os pesquisadores e as pesquisas, distinguindo o diário de um etnógrafo em diário de entrevista, diário de pesquisa e diário íntimo. No diário de entrevistas, o etnógrafo recopia e transcreve os dados anunciados por outros com foco voltado para esclarecer as questões da pesquisa. No diário de pesquisa as anotações consistem nos referentes de suas reflexões, experiências e sensações, podendo conter partes secretas, como "especulações teóricas e conceituais, das hipóteses inúteis ou abandonadas, onde a ingenuidade ou enganos registrados, se tornados públicos, teriam impacto na imagem do pesquisador" (WEBER, 2009, p. 160). E o diário íntimo, ainda que confundido com o diário de pesquisa, é elevado, "em certos casos, ao nível de diários literários, em que se leria sem farsas a 'verdade' humana da obra, e logo que publicada, podendo conhecer múltiplas variações" (WEBER, 2009, p.160).

Em sequência, considera-se a entrevista como procedimento de coleta de dados largamente utilizado e cuja principal característica para as pesquisas das ciências humanas consiste na possibilidade do encontro do pesquisador com pessoas importantes para compreender e/ou esclarecer as questões de pesquisa que são formuladas como delineadoras dos estudos. A literatura a respeito mostra a existência de vários tipos de entrevista que podem ser aplicados separadamente ou associados. São eles: entrevista estruturada, semiestruturada, formal ou informal, delimitada pela relação de perguntas mais ou menos fixas; entrevista focalizada, estruturada por temas de interesse que se difere das anteriores pela possibilidade de ser realizada para uma pessoa ou para um grupo - nesse caso, aproxima-se dos tipos definidos por pautas e por grupo focal. ${ }^{7}$

Gil (2008) é didático ao abordar as vantagens e desvantagens da entrevista, ressaltando a possibilidade de apreensão ampla da realidade, desde contextos gerais até determinadas especificidades do entrevistado, bem como de aprofundamento de temas/conteúdos preestabelecidos. Pela entrevista é ainda possível levantar informações e dados que não são produzidos por fontes documentais e tratálos, estes e as demais informações obtidas, qualitativa ou quantitativamente. Outrossim, chama a atenção para a postura e habilidade do pesquisador e para a veracidade, bem como interesse e disposição do entrevistado como desvantagens ou limitações que devem ser consideradas na proposição e na realização de entrevistas.

A essas colocações acrescenta-se a atenção para a reflexão e posicionamento do pesquisador com relação à decisão de utilizar-se da entrevista considerando o objeto de estudo e os objetivos associados aos métodos e categorias eleitas. Na transversalidade desses condutores do estudo ressaltamos os três aspectos que podem interferir em todo o escopo da pesquisa. Vale destacar que o tratamento (ou a seleção) dos entrevistados como atores é distinto daqueles que os definem ou apreendem como sujeitos. Turato (2003, p. 354) auxilia na distinção: o "sujeito" é o ser pensante e atuante na posição de participante como objeto de estudo; o "ator social" é aquele que desempenha papel na sociedade, abordado na pesquisa como representante.

Acerca do registro fotográfico, apontam-se, mesmo que de forma breve, três aspectos que elevam esse procedimento como uma das técnicas profícuas e exitosas, e que, segundo Rios; Costa; Mendes (2016), auxiliam para a compreensão da realidade exposta tanto quanto instigam a reflexão dos leitores. Ao observar a paisagem e se colocar na posição de fotógrafo, o geógrafo-pesquisador aproxima a técnica de manuseio do equipamento com a sua visão de mundo, proporcionando interação e coerência entre método e metodologia. Ao inserir a fotografia, fruto de sua observação, o geógrafo-pesquisador deve considerar e expor com clareza os limites espaciais e temporais da fotografia, considerando tratarse de um recorte da realidade. E, associando esses dois aspectos, registra-se as orientações de Milton Guran (2011), que distingue a foto ética, captada pelo pesquisador, da foto êmica, fornecida pelo entrevistado ou fruto de levantamento documental, ambas colhidas pela observação do pesquisador. Ou seja, "seu papel mais importante como método de observação, convém sublinhar, não é apenas expor o que é visível, mas, sobretudo, tornar visível o que nem sempre é visto" (GURAN, 2011, p. 92).

${ }^{7}$ A esse respeito, ver também Boni e Quaresma (2005) e Brandão (2006). 
No que diz respeito à fotografia como registro, Guran $(2011$, p. 89) assinala o fato de as fotografias se constituírem em documentos que "sobrevivem ao desaparecimento físico do referente que as criou". Acerca dos aspectos éticos, ressalta que "uma fotografia malfeita é como um texto mal escrito. A utilização da fotografia se dá através da leitura da imagem, isto é, do reconhecimento das informações nela contidas, as quais propiciam uma reflexão científica". O autor tece essas considerações após enunciar que o uso da fotografia como fonte de dados ou elemento do discurso final deve considerar: "a constituição de um corpus fotográfico; a produção da fotografia no curso da pesquisa; a leitura fotográfica; e a articulação entre texto e fotografia visando à construção de um discurso científico" (GURAN, 2011, p. 81).

Os instrumentais definidos para a pesquisa se completam com a proposta de se realizar uma oficina na Escola Municipal Aurete Pontes Fonseca, ${ }^{8}$ reforçando as trilhas perceptivas como um dos caminhos para compreender o modo como as crianças percebem a paisagem e apreender como os estudantes se relacionam com o meio, suas percepções e suas experiências. Com esse recorte a condução da oficina foi pautada nos procedimentos propostos por Vargas (2017) e a análise de acordo com os fundamentos da metodologia de mapas mentais de Kozel (2018), ressaltando o entendimento de que "as imagens são textos a serem decodificados e não formas que transmitem mensagens diretas e imediatamente apreensíveis" (CORREA, 2011, p. 16). ${ }^{9}$

Foi, portanto, com intuito de aperceber o lugar Fazenda Velha que se planejou o trabalho de campo. No chão do povoado o grupo se moveu por suas ruas, praças, condomínios, estabelecimentos comerciais; adentrou em casas e ouviu relatos de suas visões de mundo pela vivência no lugar; fotografou suas gentes, seus fazeres e coletou mensagens de crianças pela construção de mapas mentais. A seguir, o povoado é descrito pelo extrato dos relatórios elaborados, ou seja, a exposição da imagem que nós geógrafos construímos a respeito de Fazenda Velha. ${ }^{10}$

\section{AMPLIANDO O OLHAR: SUBVERTENDO AS APARÊNCIAS}

Esta seção expõe o percurso como um exercício: o que se viu, olhou e enxergou entre a materialidade e a subjetividade do observador. Coerentemente às colocações a respeito da subjetividade e densidade a serem considerados na observação etnogeográfica, os discentes participantes do percurso, ou seja, os observadores, são identificados e, de certa maneira, individualizados de acordo com a técnica de observação. Nesse sentido, subverte-se, também, a normativa textual da terceira para a primeira pessoa do singular, com o intuito de tornar visíveis as observações dos discentes e estes, como sujeitos do ato de observar da autora do texto. Assim, eles estão apresentados por seus nomes, a autora, na primeira pessoa do singular e o grupo, na terceira pessoa do plural.

Com essas ressalvas, assinala-se que a primeira aproximação ao povoado Fazenda Velha deu-se pelo depoimento de Liliane Barbosa, expondo suas impressões sobre o lugar e seus habitantes como professora da Escola Municipal Aurete Pontes Fonseca: (i) a maioria das crianças que frequentam a escola são residentes de Fazenda Velha e do condomínio Quinta da Varzinha, situado em área pertencente ao município de Esmeraldas, mas que, por situar-se muito próximo, do outro lado da BR 040, se deslocam para a Escola, recolhidos pelo ônibus da prefeitura de Sete Lagoas, que traz também as crianças desse lugar, pois as distâncias são consideráveis; (ii) a grande maioria é de família de baixa renda, cujos pais são empregados das casas dos condomínios e das chácaras que predominam nos povoados.

Em seguida, Jéssica e João Lourenço complementaram com informações sobre a socioeconomia, sobre os serviços existentes e com a sua delimitação em imagem de satélite (Figura 1). Essas

\footnotetext{
8 Única escola do povoado, foi confirmada, pelos depoimentos, como um de seus referentes e marcos da paisagem. A oficina foi realizada com estudantes do $5^{\mathrm{a}}$ ano que elaboraram mapas mentais sobre o percurso da casa à escola ${ }^{9}$ Roberto Lobato Corrêa discorre sobre a abordagem de paisagem e imagem de Denis Cosgrove.

10 Os relatórios foram produzidos pelos participantes, quais sejam: Adília Jardim Silva; Ana Carolina Santos e Silva; Crisângela Élen de Souza, Gabriela Carneiro Reis; Guidyon Augusto Almeida Lima; Inácio Andrade Silva; Jessica Poliane Gomes dos Santos; João Lourenço dos Anjos; Jorge Duarte Rosário; Liliane de Deus Barbosa; Liliane Rodrigues de Oliveira Braga; Luciana Priscila do Carmo; Ludimila de Miranda Rodrigues Silva; Mariana Rodrigues da Costa Neves; Rhayan de Carvalho Alves. Registra-se ainda a participação dos professores José Antonio Souza de Deus e Sônia Menezes.
} 
informações foram valiosas sobretudo para comporem uma imagem do lugar: (i) parece que está muito próximo de Esmeraldas, um lugar estigmatizado pela violência, dadas as constantes notícias de "desova de cadáveres e esconderijos"; (ii) o arruamento que se vê pela imagem de satélite denota um relevo acidentado e uma ocupação dispersa; (iii) a proximidade de Sete Lagoas e o acesso pela BR040, possivelmente, justificam a instalação de condomínios, bem como de serviços como bar, restaurante, armazém, floricultura e associação de moradores.

Figura 1 - Aproximações cartográficas: o povoado Fazenda Velha.

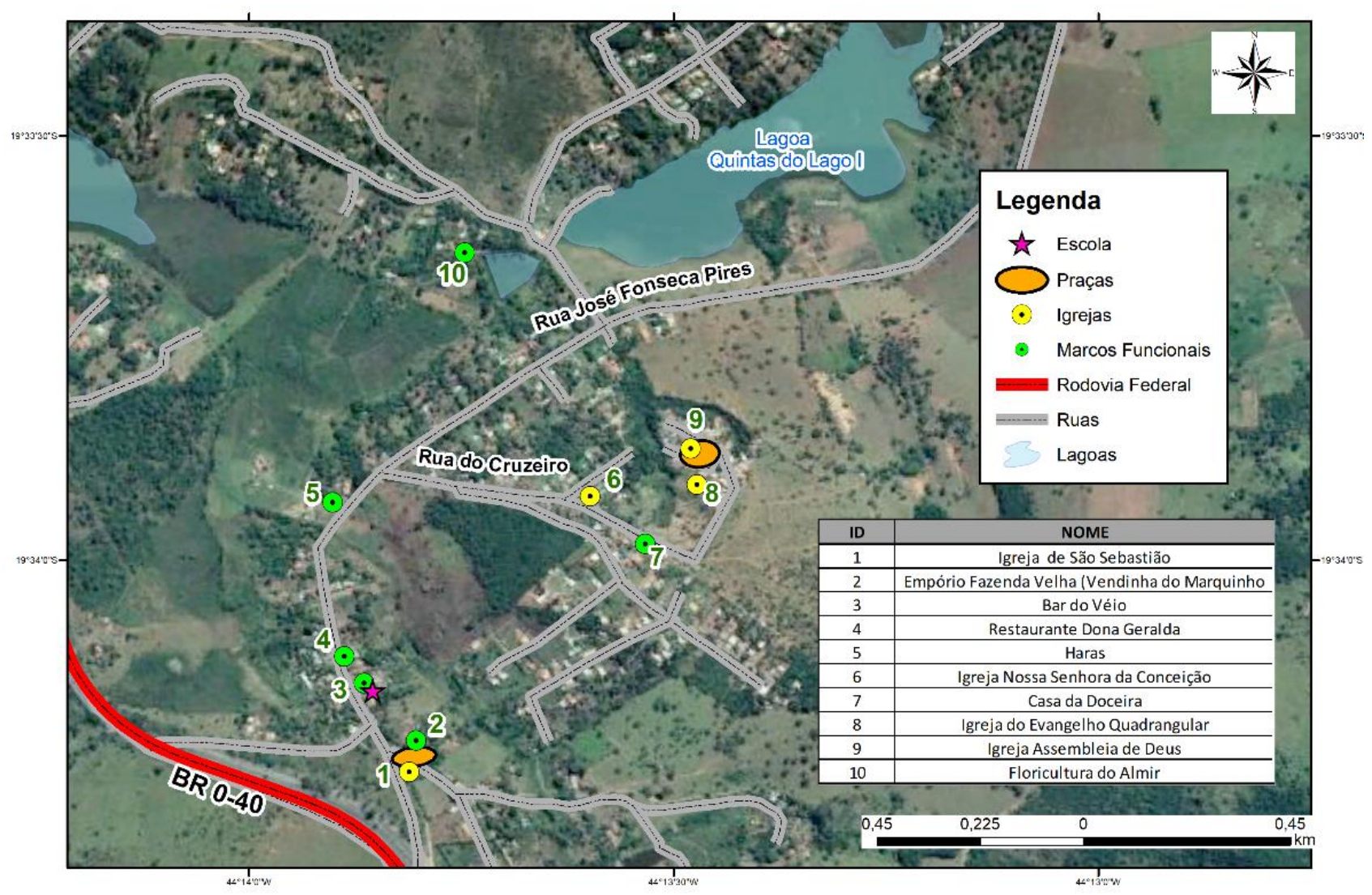

Fonte - Imagem Google Earth, 2018; IBGE (2010). Elaboração - Jessica Poliane Gomes dos Santos.

Mas como assinala Paola Sabbion (2016), para uma paisagem ser definida, ela deve ser percebida, de forma a construir uma ligação inseparável entre o ambiente circundante e a experiência. De modo distinto de Paola Sabbion, que trata da relação entre paisagem e ecologia, Elvira Petroncelli (2019) foca nos conteúdos da Convenção Europeia das Paisagens e conclama à reflexão quanto ao reconhecimento da existência de uma estreita relação da comunidade com a paisagem. Nesse sentido, suas abordagens se aproximam, pois reforçam o caráter relacional da paisagem, seja pela observação/percepção do olhar do pesquisador, seja pelo papel ativo que a comunidade exerce na transformação da paisagem, posicionando-a como seu referente.

Foi, portanto, com essas intenções que consolidamos o entendimento de que nosso campo iria ao encontro de reconhecermos a relação da comunidade com sua paisagem, buscando apreender o papel que a comunidade exerce em sua transformação, ao mesmo tempo em que ela se constrói como referência, como ancoragem do lugar.

Como se observa na Figura 1, a poucos metros da BR-040 situam-se um armazém e, no seu entorno, uma igreja católica, um ponto de ônibus e um prédio que abriga o Posto de Saúde, os Correios e a sede da Associação dos Moradores. O ônibus estacionou sob a sombra de uma frondosa espatódea e estabeleceu-se meia hora para colhermos as primeiras impressões (Figura 2). 
Figura 2 - Primeiras impressões de Fazenda Velha: ao adentrar no povoado o visitante se depara com a igreja de São Sebastião à direita; o prédio que abriga os Correios, o Posto de Saúde e a Sede da Associação à esquerda e, à sua frente, um empório, cujas prateleiras são ocupadas por diversos produtos.

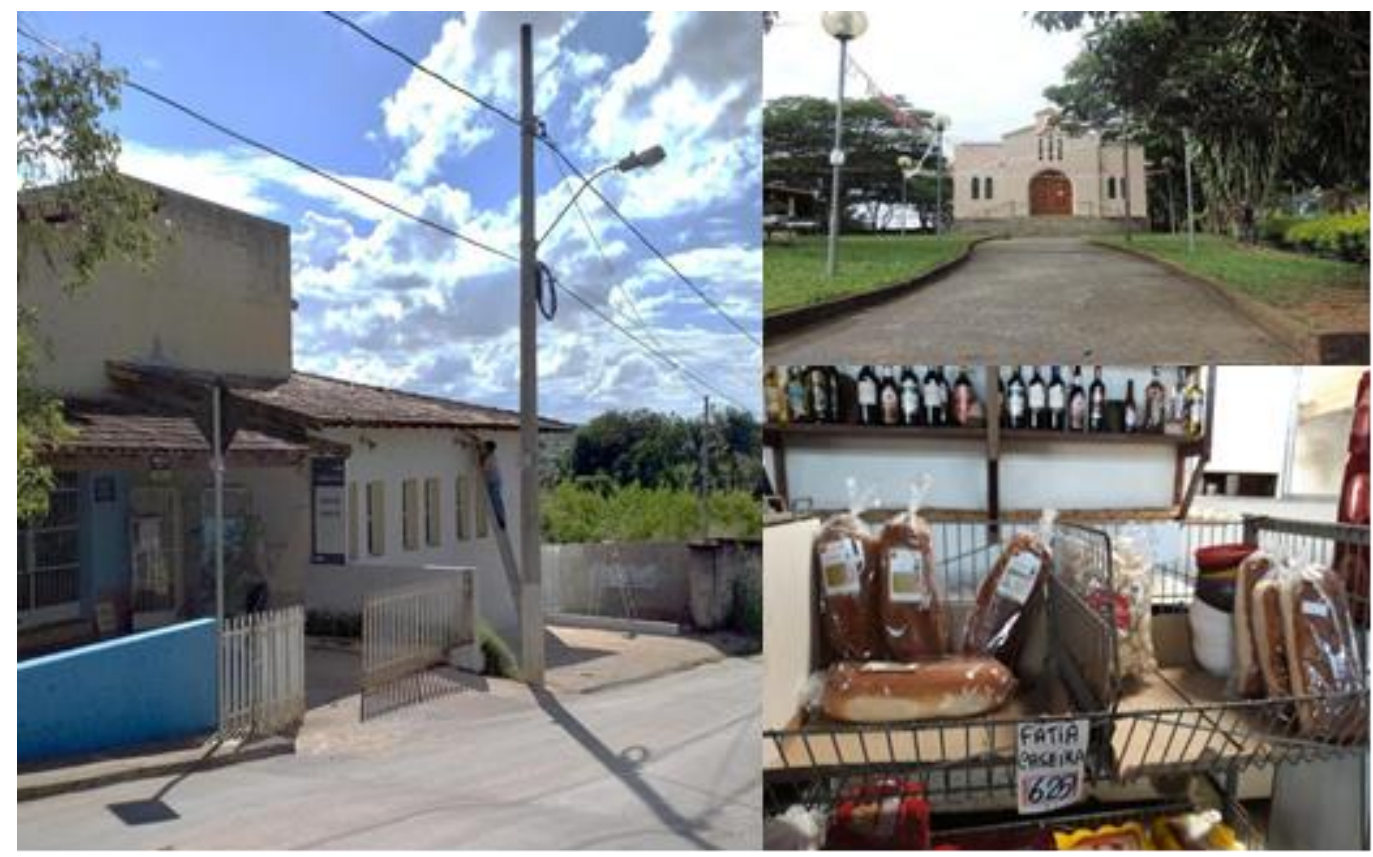

Fonte - Pesquisa de campo, abril, 2019. Fotos - Maria Augusta M. Vargas; Inácio Andrade Silva; Mariana Rodrigues da C. Neves, 2019.

De pronto, direcionei as atenções para o prédio dos Correios onde se realizou a primeira entrevista. A funcionária, muito ressabiada, informa ser residente desde sempre ("nunca morei em outro lugar"), evitou informar e expor sobre o lugar, transferindo os "não sei" para pessoas que sabem, e indicando nomes, dentre os quais foram anotados Marquinhos do Empório, D. Lia, Sr. Egmar, D. Maricota. Para ela, a imagem de Fazenda Velha é o Empório do Marquinhos (o armazém defronte, onde estacionamos o ônibus), pois "ele é antigo aqui e já herdou o ponto de seu pai". Como o pessoal do Posto de Saúde estava ocupado com o acolhimento, os dois senhores sentados no banco disseram que sabiam "tudo exatamente como a moça falou", ou seja, prestaram atenção na prosa e, como ela, foram muito contidos na informação.

Diante das dificuldades enfrentadas, fui ao encontro do grupo que já havia adentrado no Empório/Venda de Marquinhos o suficiente para extrair um pouco da história do lugar. $\mathrm{O}$ armazém é muito antigo mesmo e foi estabelecido pelo pai do Sr. Marquinhos, que atendia à região com secos e molhados. Relata o Sr. Marquinhos:

A povoação mais próxima daqui teve início a uns dois quilômetros em direção a Sete Lagoas, no antigo Posto Fiscal, denominada Das Pedras. Lá tinha uma escola rural "Leonídio Pires Fonseca" e aqui, perto do armazém de meu pai, tinha uma sede abandonada por Leonídio, [cujo lugar era] chamado de Fazenda Velha. Com o fechamento do Posto Fiscal, a localidade Das Pedras começou a diminuir e parar de crescer, e aqui perto da casa da Fazenda Velha começou a crescer pela influência do Sr. Leonídio, inclusive dando o nome de sua neta Aureta à Escola que se transferiu para cá. Assim a localidade Das Pedras [na Figura 1, próximo a lagoa que aparece à NW] fica com o nome na história e aqui começa a crescer e a ser conhecido como bairro Fazenda Velha, que foi dominando e crescendo. Tem muita gente de fora que tem terra, chácara e casa nos condomínios. O movimento dessas pessoas não é certo, mas são eles que fizeram Fazenda Velha crescer. A sede do povoado é o Haras Fazenda Velha, onde acontece a Festa do Cavalo há 8 anos.

Para Inácio, a diversidade de produtos oferecidos no Empório/Venda do Sr. Marquinhos salta aos olhos. O empório segue padrões antigos de produtos, desde alimentícios a itens de higiene pessoal, dispostos entre objetos e utensílios de uso cotidiano do passado, explicado pelo comércio que se faz há gerações. Foi possível enxergar nesse espaço balanças antigas, calculadoras, máquinas de escrever, urinóis, 
bules etc. Um vislumbre da globalização em que alimentos tradicionais - queijos, broas, bolos - são oferecidos juntamente com energéticos e macarrões instantâneos. O dono informa que os energéticos são oferecidos aos trilheiros que passam regularmente pela venda aos finais de semana. A união dos membros da comunidade é ressaltada e são citadas D. Lia e D. Maricota como pessoas que merecem ser conhecidas.

Com essas primeiras informações foi decidido percorrer as ruas principais do povoado de ônibus para, posteriormente, nos dispersarmos em pequenos grupos. Assim, tomamos a rua José Fonseca Pires, que dá acesso aos condomínios Quintas do Lago I e II, e, posteriormente, a rua do Cruzeiro, que dá acesso ao condomínio Chácara Ecológica e ao Alto do Cruzeiro. Com o olhar dos "de fora", observamos uma paisagem que se altera ora por muros altos, ora por pastos, ora por portais, ora por alinhamento de casas mais simples, até alcançar um largo com uma pequena capela e mais adiante uma praça rodeada por casas de fachada frontal, muitas sem acabamento e em lotes muito pequenos.

Ana Cristina e Crisangela ficaram nesta Praça em cujo entorno situam-se duas igrejas evangélicas. Entrevistaram a pastora Angela, que ligou a origem do nome do povoado "à existência de um casarãosede de uma fazenda/engenho abandonado". Já a denominação da Praça e das ruas do bairro Alto do Cruzeiro, com nomes de origem hebraica, foi feita

\begin{abstract}
por mim quando era presidente da Associação de Bairro, devido à influência da Igreja do Evangelho Quadrangular sobre o cotidiano dos habitantes locais. Desde 1987 quando consegui uma concessão de terreno da prefeitura e repassei para famílias carentes que moram aqui no entorno da Praça Jeová Jiré.
\end{abstract}

Ambas apreenderam o sítio como um enclave definido pela opção religiosa e organizado socialmente pela Pastora.

Ainda no alto da rua do Cruzeiro, Inácio e Sonia entraram na casa de D. Maricota, a doceira mais conceituada de Fazenda Velha. Reside no lugar desde os 4 anos. Segundo ela, antigamente se plantava de tudo por ali e foi deixado de lado, "devido à divisão da localidade em chácaras". Assim passaram a fornecer aos moradores locais outras formas de remuneração mais relacionadas ao modo de vida urbano, mesmo que a atividade realizada seja do meio rural. D. Maricota abre as portas de sua casa e mostra o seu saber de doceira, sua renda extra. Ela mostra o cômodo em que armazena os doces, as embalagens e a balança que afere o peso dos doces vendidos a $R \$ 20,00$ o quilo. Na cozinha ainda preserva o fogão a lenha, atualmente sem uso por causa da saúde. Em seu quintal as frutíferas que abastecem seus tachos de doce: marmelo, jabuticaba, acerola, laranja-da-terra, goiaba, mamão e bananeiras, que não são suficientes para a sua produção, passando a contar com o abastecimento de vizinhos e com o que é colhido em pastos e matas próximas. Para festas, ela aceita encomendas de salgados, sendo o pastel o quitute preferido, e comidas como o tutu de feijão, carne, frango e macarronada. A produção não envolve a família. Ensinou filhos e noras, mas ninguém se interessou, vindo a contar com a ajuda e participação de uma sobrinha. E, quanto ao envolvimento dos moradores, explica que a presença nas reuniões da Associação "é pequena', mas que são muito unidos quando alguém da comunidade está em dificuldade".

Liliane Braga, Guidyon e eu saltamos do ônibus no largo da pequena capela católica que, em virtude de uma grande cruz à sua frente, é denominado largo do Cruzeiro e, nesse ponto, fomos abordados por dois senhores, curiosos sobre nossa presença: "Tanta gente em um ônibus!". Sr. Valdemar, um homem pequeno com aparelho auditivo, empurrava um carinho de mão vazio em direção ao portão de uma chácara, sua residência. No pescoço, chamou nossa atenção o colar que emoldurava seu dorso até o quadril, um barbante grosso de aproximadamente $80 \mathrm{~cm}$ com molhos de chaves a cada 10/15 $\mathrm{cm}$.

Tomo conta de nove casas de parentes e conhecidos. Os parentes foram chegando, como eu, de Capim Branco. Saíram e mantiveram as casas que eu tomo conta, porque gostam muito daqui e eu também. Aqui esse alto é muito especial devido à igrejinha de Nossa Senhora do Rosário, que aliás ajudei a reformar. Estava muito acabadinha. Fizemos um mutirão de ajuda para reformar e fazer a festa este ano. Lia é a comandante da Congada que alegra todo mundo. A procissão esse ano foi grande, longa e muito bonita.

O Sr. Nelhio faz uma brincadeira com o amigo: "Valdemar é o prefeito dessa parte do povoado, pois cuida de toda a redondeza [aponta a mão com o braço estendido para todos os lados fazendo um círculo], cuida de tudo que precisa cuidar há uns 40 anos". 
Crisângela adentra a casa de $\mathrm{D}$. Lia e é muito bem-recebida pela comandante da Congada e também única benzedeira do lugar. $\mathrm{O}$ dia de campo era também o aniversário de $\mathrm{D}$. Lia, com a casa cheia de visitas. Ela contou que com 14 anos sonhava com um terço branco e com 18 anos sonhou com Nossa Senhora com dois terços na mão e, ao tentar ver o rosto dela, acordou. Desde então começou a benzer. Quanto à Festa de Nossa Senhora do Rosário, diz que "é muito linda, mas já estou cansada, e aí vem sempre um e fala para não desistir e vai acontecendo, um ajuda aqui, outro ali, e eu e meu marido vamos todo ano". Ao falar para ela que também era rainha Conga (Congada, manifestação popular tradicional e ainda significativa em Minas Gerais), D. Lia ficou feliz: "Ainda bem que os mais novos estão pegando a tradição". E assim nos despedimos com a promessa de voltar em um melhor dia para conversar sobre ela e seus ancestrais.

Ao descer a rua do Cruzeiro em direção "à entrada" do povoado, encontramos os dois senhores que estavam assentados no banco dos Correios que foram logo acenando e nos informando: "O Egmar, presidente da Associação, está procurando a professora lá em baixo, perto do Bar do Velho, bem perto da Escola". Nesse momento entendemos que, com o aval do Sr. Egmar, éramos bem-vindos e a partir daí foram mais perceptíveis a recepção e a acolhida pelos demais entrevistados, sobretudo ao sermos informados de que a comunidade possui um sistema de segurança por WhatsApp, em que se comunicam sobre qualquer fato extraordinário. Sr. Egmar informou que avisou à comunidade que sabia de nossa vinda, por intermédio do contato de João, e com isso acalmou os ânimos dos ressabiados. Assim, a princípio "estranhos" passamos a ser acolhidos pela comunidade.

Como asseverou Cardoso (2004, p. 95) sobre a observação e o engajamento do pesquisador, "o critério para avaliar as pesquisas é principalmente sua capacidade de fotografar a realidade vivida. Sua função é tornar visível aquelas situações de vida que estão escondidas e que, só por virem à luz, são elementos de denúncia do status quo". Até o momento observamos, no sentido de analisar com atenção, que apenas as lideranças e pessoas mais antigas no povoado haviam se prontificado a falar conosco e, considerando, o ocorrido, chamamos a atenção para a importância de, ao se proceder à pesquisa de campo, por curto ou longo período, ter a certeza de que se "entrou na área de estudo". Ainda, que o pesquisador não deve recuar no enfrentamento de situações adversas de qualquer natureza, e essa foi nossa atitude ao atuarmos em um campo de apenas um dia, ancorados pelo roteiro de entrevista/observação e inspirados pelas orientações de Brandão (2007, p. 20): "Eu costumo, para meu gosto, dizer o seguinte: que numa pesquisa existe um trabalho de observação sistemática. Chegar num lugar e observar organizadamente, fazendo croquis, aquilo que está acontecendo ou, então, uma estrutura de relações".

Foi-nos exposto, pelo presidente da Associação, que sua criação ocorreu em 1985. Mas no decorrer da entrevista apreendemos ser um dos Conselhos de Desenvolvimento Comunitário do município de Sete Lagoas, que a população o tem como "associação". E por se tratar de um Conselho, explica: "Mantemos o diálogo contínuo e aberto com a prefeitura, ou seja, faz parte da estrutura municipal". Ao chamar a atenção sobre a preocupação com a segurança, acrescentou:

Compramos a cada período de cinco anos um carro e o cedemos como comodato à Polícia e, embora eles não sirvam exclusivamente à comunidade, nos atendem com presteza sempre que precisamos, como no caso do sequestro. Bem, nós agimos em conjunto pois o grupo de WhatsApp ALERTA ajuda a rapidamente entrarmos em contato com a polícia e também contamos com câmaras instaladas em pontos estratégicos. Já o outro grupo de WhatsApp AMIGOS serve para informações, trocas de ideias e ajudas mútuas.

Indagado se trocaram informações sobre nossa chegada, sorriu e, diante do sorriso, entendemos que se relacionaram no grupo ALERTA. Com essas informações ele enfatiza a união dos moradores do povoado, "tanto os fixos quanto os esporádicos que possuem chácaras e casas nos condomínios de uso ocasional". E finda expondo que "foi assim com bingos, rifas, pedágios e sorteios que construímos o Posto de Saúde, os Correios, os banheiros comunitários, a associação; prédios que ficam na entrada do povoado, com muito orgulho".

Adilia, Luciana Priscila, Gabriela, Crisângela, Mariana, Jessica, Ana Carolina e Liliane Braga entraram na sede da Fazenda Velha, denominada Haras pelos moradores. Entre fotos internas e externas, passeios a cavalo e entrevista com empregados foi revelado que a casa fora transportada de Diamantina, ou seja, desmontada e montada aqui "há poucos anos". Com essa informação foi possível entender que a casa do século XIX não é a responsável pela toponímia Fazenda Velha e, sim, que foi erigida para "reforçar" o nome do povoado, agregar valor ao haras e marketing para a Festa do Cavalo que se realiza na propriedade e cuja oitava edição ocorreu em 2019 (Figura 3).

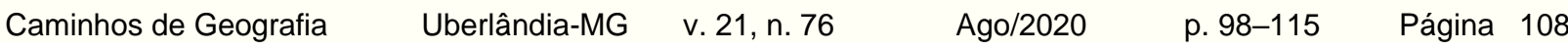


Figura 3 - Casa sede do haras: fachada; detalhe interior do telhado e visão da varanda e dos fundos.

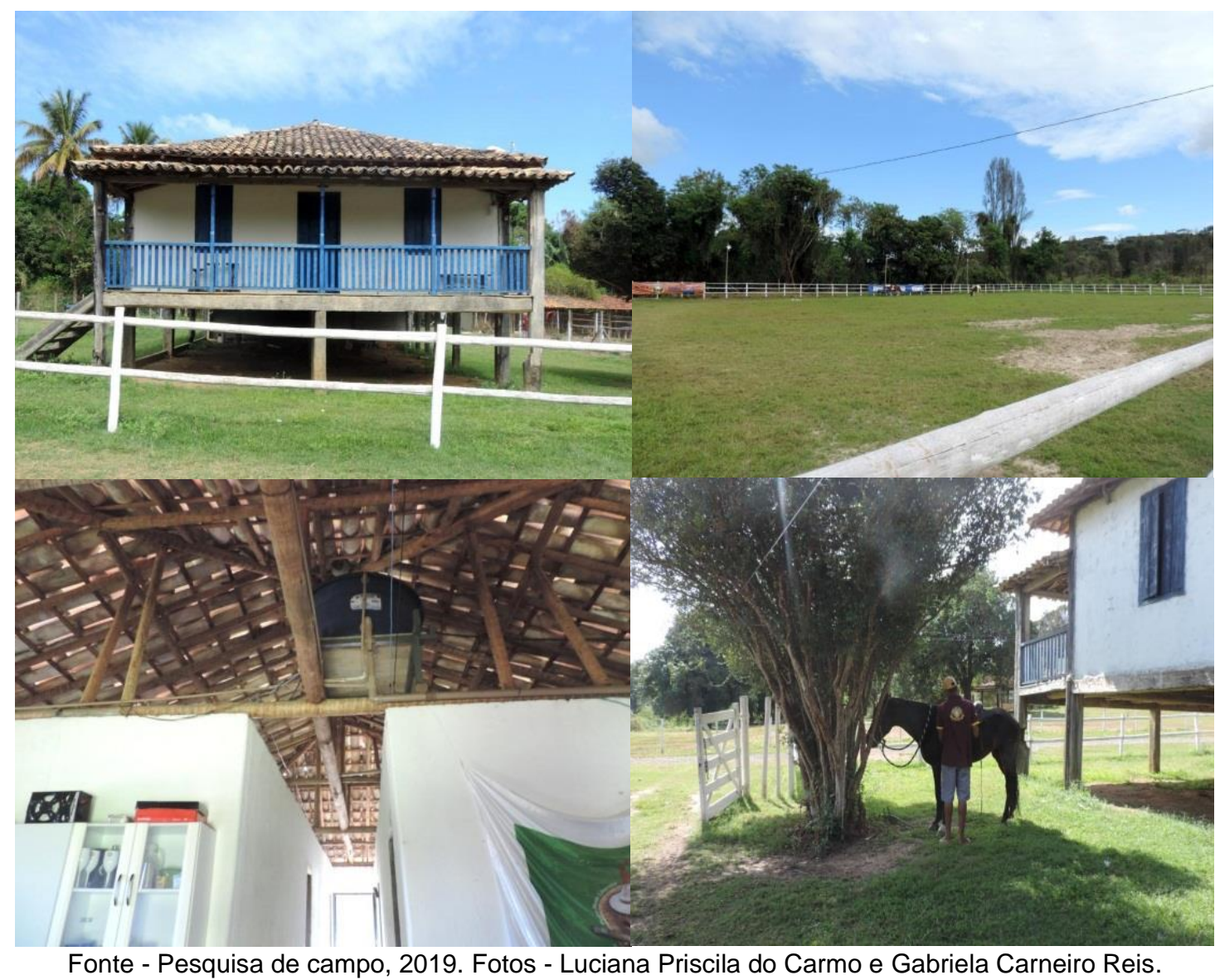

Assim como eu me surpreendi com a desconfiança em relação à nossa chegada como estranhos identificados pela conexão da rede ALERTA, Adília se sentiu outsider ao se deparar com a casa-sede do haras, bem visível da rua principal, pois tinha "certeza de que seria essa casa que daria nome ao povoado". Compreendemos a denominação dos moradores como "haras", e não Fazenda Velha (como, "lá no haras, festa do Cavalo no haras"), bem como a versão do surgimento da povoação fornecida pelo Sr. Marquinhos ser a mais plausível. Como registra Raffestin (2010, p. 15), a paisagem revela e esconde, pois "é um produto da territorialidade que resulta de um conjunto de relações mediatizadas, produto expresso por meio de diversas linguagens, em certa escala".

Adilia complementa que os condomínios se fazem como lugares dentro do lugar Fazenda Velha, inclusive com denominações próprias, ao que refletimos indagando se Fazenda Velha se transformou em "rugosidade" no sentido espaço temporal dado por Milton Santos. Estariam os moradores inseridos na horizontalidade do domínio do contíguo, ou seja, dos vizinhos reunidos por uma continuidade territorial, e os proprietários das segundas residências dos condomínios e chácaras representantes das verticalidades, como pontos distantes uns dos outros que se ligam pelas formas e processos sociais? ${ }^{11}$ Seria uma "paisaje relictos" uma "incongruência entre a paisagem visual e seus processos"? ${ }^{12}$ Ou, as relações e processos seriam mais bem apreendidos pela tipologia de Cosgrove $(1999,2012)$ ao distinguir o espaço dos moradores como uma paisagem "residual", reveladora da falta de condições de desafiar as ações formadoras da paisagem "dominante" impressa pelos condomínios e pelas chácaras? ${ }^{13}$ (Figura 4).

11 Cf. Santos (1996, 1998).

12 Cf. García-Romero; Muñhoz-Jiménez (2002).

13 Genericamente pode-se afirmar um ou outro a depender dos interesses do pesquisador. Mas justificar pelos caminhos de Milton Santos, Arturo García-Romero, Julio Munoz-Jiménez ou de Dennis Cosgrove carece de itinerários metodológicos que extrapolam a observação de campo realizada. 
Figura 4 - Padrões de ocupação distintos: entradas de novos condomínios; de chácara, casas de moradores do povoado Fazenda Velha e praça Jiré.

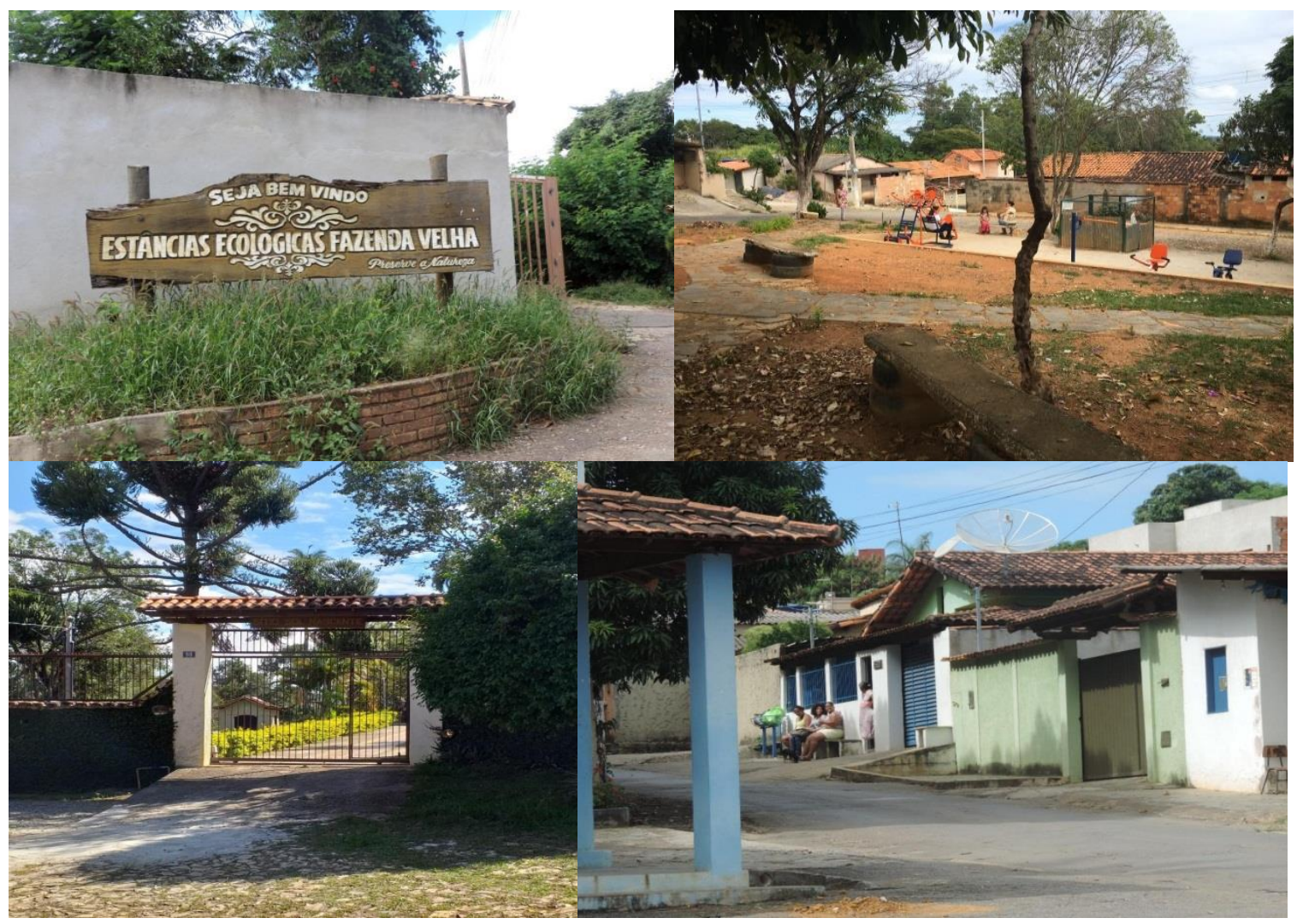

Fonte - Dados de pesquisa, 2019. Fotos - Gabriela Carneiro Reis.

Com efeito, os objetos sinalizam conflitos entre o espaço vivido e o espaço global, dito de outra forma, entre o local e o global, entre o dominante e o dominado, entre o dominante e o residual. Citam-se algumas observações: Luciana Priscila entrevistou um senhor tão conhecido quanto o Sr. Marquinhos, pelo fato de ter sido contemplado com a reforma de seu carro velho pelo programa de TV Caldeirão do Hulk; a placa na entrada do armazém do Sr. Marquinhos chamou a atenção de todos: " Favor tirar o capacete para entrar"; muros altos caracterizam as chácaras; placas de "vende-se ovos, vende-se pão; vende-se doces; vende-se temperos; tele-entrega de lanches de terça a domingo", dentre outras, denotam as ocupações principais de uns e extras de outros, e as placas "vende-se esse imóvel" em algumas chácaras denotam a atual crise econômica ocorrente no país.

Complementando a observação, apresentamos, mesmo que de maneira reduzida em face da riqueza de material recolhido, a vivência na Escola Municipal Aurete Pontes Fonseca. Ludimila, Mariana, Ana Carolina, Liliane Barbosa e eu adentramos na escola no período da manhã e, em conjunto, mantivemos contato com a diretoria, professores, funcionários e alunos. As informações já fornecidas por Liliane Barbosa com relação ao perfil dos estudantes e à evolução da ocupação de Fazenda Velha foram confirmadas, reafirmando a Escola como uma instituição referente do lugar visitado. A realização de uma oficina foi prontamente aceita e sugerida pela direção de que sua realização poderia ocorrer com as duas turmas do $5^{\circ}$ ano no período da tarde.

Objetivamos com essa atividade tomar os desenhos como instrumento da pesquisa na expectativa de inseri-los na produção de informações sobre Fazenda Velha, ou seja, tomar os mapas mentais como meio para se conhecer a realidade. E, pela experiência subjetiva com o lugar e sua paisagem, consideramos a análise de mapas mentais proposta por Kozel $(2001,2018)$ como norteadora de nosso diálogo com Fazenda Velha e sua paisagem como representação das vivências e dos valores de seus habitantes, sujeitos de nossa pesquisa. Salete Kozel sugere a análise de acordo com as características de representação (i) dos elementos da paisagem natural; (ii) dos elementos da paisagem construída; (iii) dos elementos humanos, auxiliados pela observação dos signos que se repetem, da forma de implantação e distribuição dos ícones nos desenhos. 
Em resumo, foi solicitado aos estudantes que representassem o percurso cotidiano para a escola por meio de um desenho "todo seu", com o entendimento de que uma oficina se constitui em uma prática que articula "foco, plasticidade" e produz "construções conversacionais dialógicas" (SPINK; MENEGON; MEDRADO, 2014, p. 33). Foco no percurso da casa à escola; plasticidade pela expressão de objetos e cenas em cores e perspectivas diversas, na expectativa de nossa análise da percepção da paisagem, ou seja, o dialogismo entre as percepções e os saberes dos estudantes e os nossos.

Dentre os 28 mapas mentais produzidos por doze meninas e dezesseis meninos com idade entre $10 \mathrm{e}$ 14 anos apreendemos de imediato a exposição da paisagem de dois povoados: Fazenda Velha e Varzinhas, este "fora" de nosso alcance de observação! Surpreendentemente, onze estudantes residem em Varzinhas, pertencente ao município de Esmeraldas, e seus mapas mentais mostraram, com maior ou menor detalhe, a travessia da BR-040. Todavia, observam-se semelhanças entre a percepção das crianças dos dois povoados pelo predomínio de ícones urbanos, tais como igreja, bar/vendas, o ônibus, postes, placas, ruas com detalhamento de asfalto, calçamento, terra, e até buracos! Os mapas de Fazenda Velha se distinguem, nesse sentido pela representação da escola, e os de Varzinhas pela representação da BR 040 e do Posto Fiscal, sinalizando, pela nossa solicitação de representação do percurso, que eles são os "de lá", posto que a centralidade (ou o ponto final) está dada pela escola.

Os elementos da paisagem natural mostraram-se bem menos numerosos que aqueles da paisagem construída e, portanto, mais observados - e consequentemente mais representados, pelas meninas. As representações trouxeram árvores, sol e nuvem preponderantes, mas, especificamente, chamaram atenção aquelas que imprimiram a distinção entre o urbano e o rural - com cercas, animais e pastos. As etnogeograficidades que, para Silva (2019), traduzem a paisagem cultural pela apreensão do cotidiano e exposição da relação com o meio, estão representadas pela estreita relação com a família (muitos sinalizam minha casa), pela significativa representação associada ao ônibus escolar e à minha escola), pela percepção das ruas, placas e animais que são vistos no percurso, dentre outros (Figura $5)$.

Figura 5 - O percurso da casa à escola: detalhes dos equipamentos de lazer e religiosos, distâncias e sentidos percorridos, cercas e rodovia que separam e segregam.

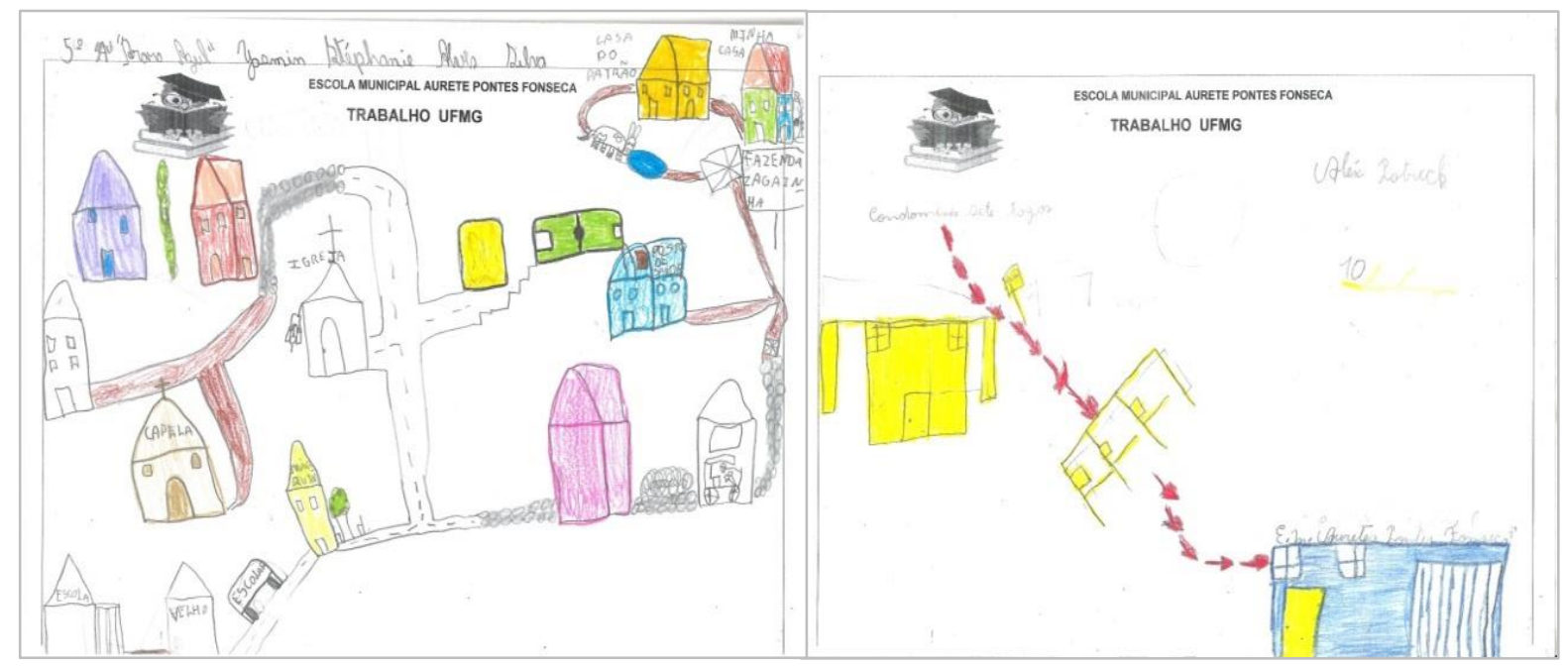

Fonte - Pesquisa de campo, abril, 2019. Desenhos - Oficinas realizadas na Escola Municipal Aurete Pontes Fonseca. Org. Maria Augusta Mundim Vargas.

Tanto quanto os depoimentos dos moradores, as crianças partilharam nossos interesses e trouxeram paisagens reveladoras: os condomínios individualizados por portões que os isolam ou os segregam como filhos de empregados; os povoados Fazenda Velha e Varzinhas separados pela BR 040; a visão romantizada de natureza pelos sóis coloridos e céus com pássaros entre nuvens; a percepção de distâncias entre suas casas e a escola, dos serviços ofertados que lhes interessam como o bar do Velho, ao lado da escola que oferece guloseimas, campo de futebol, enfim, os acessos (ou não acessos) que suas mentes produzem em querer e não querer. 


\section{CONSIDERAÇÕES FINAIS: SOBRE PRÁTICAS, VIVÊNCIAS E SOCIABILIDADES}

Ao término desta exposição resta destacar as vivências com a turma, que também se inserem em nossas reflexões. Os encontros cotidianos possibilitaram propor e realizar um trabalho de campo e destacar não somente as sociabilidades, mas o quanto nos relacionamos e o tanto que produzimos de conhecimentos.

Ao propor o trabalho de campo em Fazenda Velha a atenção à espacialidade norteou e abriu os sentidos às novas experiências pela expectativa com a visita: observar conjuntos, singularidades, pessoas etc., posicionando a observação como construto de nossa percepção. $\mathrm{E}$, ao planejar, o campo foi tomado como um exercício da observação ancorado pela epistemologia e pela pedagogia provocadoras de novas indagações ao tempo em que fortaleceram e legitimaram nosso fazer geografia. Comungamos com Claval $(2013$, p. 142) ao afirmar que "o trabalho de campo nas ciências sociais se mostra como equivalente em laboratório nas ciências experimentais", e é assim que se rompe com as epistemologias tradicionais.

(Re)viver essa vivência foi também um ato de observação delineado pela dimensão subjetiva que encerra as razões e os sentidos de ser e de estar no Instituto de Geociências nesse abril de 2019. Esse posicionamento relativiza a subjetividade no que diz respeito ao eu-aqui, singular com as bagagens pessoais e o eu-ser universal, com a consciência de ser e estar no mundo (HEIDEGGER, 2012).

Entre as práticas, vivências e sociabilidades, foi possível observar as posturas de cada um com relação às suas pesquisas, o trato com as categorias, objetos, sujeitos, procedimentos e técnicas e, dentre elas, a observação. A observação adquiriu, nesse contexto, o sentido de pulsar com atenção: expectativa com o que está por vir diante dos questionamentos no contexto acadêmico de conhecer, vislumbrar, desvelar e, intimamente, admirar, vibrar, reconhecer e valorizar. É, certamente, um movimento que pulsa!

Ou seja, é saber sobre a dimensão do estar aqui enquanto ser-no-mundo e observar a dedicação no planejamento do trabalho de campo, bem como a observação inserida no processo de construção metodológica com bom senso e rigor empírico. Assim, pode-se vislumbrar a tessitura de sociabilidades. Estas foram delicadamente postas pelos abraços, olhares, assertivas de cabeça; sutilmente construídas nos debates e nas ruas de Fazenda Velha; amigavelmente enlaçadas pelos quitutes da cozinha mineira levados todos os dias e também por aqueles descobertos da cozinha de $D$. Maricota, que foram partilhados "em festa", e, ainda, pela entrega (no sentido de passar algo para o outro) de experiências, de abordagens que enriqueceram a Geografia e consolidaram afetos.

E a paisagem? Entre as exposições constitutivas de Dardel (2011), Berque (1998) e Cosgrove (1999, 2012), dentre outros, delinearam-se entrevista, diário de campo, registro fotográfico e oficina como procedimentos iniciados e perpassados pela observação da paisagem de Fazenda Velha. Como pontua Peirano (2016), o percurso etnográfico dá-se pela vivência com o andar, ver e escrever. Para ela, andar, ver e escrever, tudo isso converte as fases essenciais da etnografia - situar-se, observar e descrever, em atividades sincrônicas com o percurso de encontros, sensações e descobertas.

É, com efeito, o ato de observar e o rigor para com a observação que aproximam esse trabalho de campo do exercício de redução fenomenológica realizado por Serpa (2019) com seus alunos sobre a paisagem da cidade de Salvador. Como descrever sem observar? Como comparar sem descrever? Como relacionar sem comparar? Afinal, o conceito de paisagem se constrói pela observação: tudo o que nossa vista alcança. Como dito por Santos (1998, p. 61), "tudo aquilo que nós vemos, o que nossa visão alcança, é a paisagem [...] não apenas formada por volumes, mas também por cores, movimentos, odores, sons, etc.". É a observação que conduz e que é conduzida pelo olhar do pesquisador, o quanto enxerga, o quanto ouve, o quanto dialoga com sujeitos e métodos.

Um dia de campo pode vir a ser mais que registros, encontros e sensações: um marco reflexivo. A paisagem não resulta no elenco/identificação de seus elementos e marcos geográficos, mas, fundamentalmente, da forma de interpretação que individual, social ou metodicamente fazemos dela. Permanecem inquietudes entre o que se vê e os processos constitutivos, entre a objetividade dos elementos da paisagem e as subjetividades das formas de interpretação.

E, assim, foram tecidas e desfeitas algumas redundâncias e essencialidades da observação no estudo da paisagem. 


\section{REFERÊNCIAS}

BERQUE, A. Paisagem-marca, paisagem-matriz: elementos da problemática para uma Geografia Cultural. In: CORRÊA, R. L.; ROSENDAHL, Z. (Org.). Paisagem, tempo e cultura. Rio de Janeiro: Ed. UERJ, 1998. p. 84-91.

BOIN, F; BURIGO, B. D. Quem tem medo de etnografia? Revista Contemporânea de Educação, Rio de Janeiro, v. 13, n. 26, p. 10-30, 2018. https://doi.org/10.20500/rce.v13i26.12243

BONI, V; QUARESMA, S. J. Aprendendo a entrevistar: como fazer entrevistas em ciências sociais. Revista Eletrônica dos Pós-Graduandos em Sociologia Política da UFSC, Florianópolis, v. 2, n. 1, p. 68-80, jan.-jul. 2005.

BRANDÃO, C. R. Pesquisa participante: a partilha do saber. Aparecida, SP: Ideias e Letras, 2006.

BRANDÃO, C. R. Reflexões sobre como fazer trabalho de campo. Sociedade e Cultura, Goiânia, v. 10, n. 1, p. 11-27, jan. -jun. 2007. https://doi.org/10.5216/sec.v10i1.1719

CARDOSO, R. C. L. Aventuras de antropólogos em campo ou como escapar das armadilhas do método. In: CARDOSO, R. C. L. (Org.). A aventura antropológica. 4. ed. São Paulo: Paz e Terra, 2004. p. 95-105.

CLAVAL, P. A paisagem dos geógrafos. In: CORREA, R. L.; ROSENDAHL, Z. (Org.). Paisagens, textos e identidade. Rio de Janeiro: Eduerj, 2004. p. 13-74.

CLAVAL, P. Geografia cultural: um balanço. Revista Geografia, Londrina, PR, v. 20, n. 3, p. 5-24, 2011.

CLAVAL, P. Le rôle du terrain en géographie: des épistémologies de la curiosité à celles du desir. Revista Confins, São Paulo: USP, n. 17, p. 1-17, 2013. https://doi.org/10.4000/confins.8373

CORRÊA, R. L. Denis Cosgrove: a paisagem e as imagens. Espaço e Cultura, Rio de Janeiro: Uerj, n. 29, p. 7-21, jan./jun. 2011. https://doi.org/10.12957/espacoecultura.2011.3528

COSGROVE, D. Geografia cultural do milênio In: CORREA, R. L.; ROSENDAHL, Z. (Org.). Manifestações da cultura no espaço. Rio de Janeiro: Eduerj, 1999. p. 17-48.

COSGROVE, D. A Geografia está em toda parte: cultura e simbolismo nas paisagens humanas. In: CORREA, R. L; ROSENDAHL, Z. (Org.). Geografia cultural: uma antologia. Rio de Janeiro: Eduerj, 2012. p. 219-238.

DARDEL, E. O homem e a Terra: natureza da realidade geográfica. Tradução de Werther Holzer. São Paulo: Perspectiva, 2011.

GARCÍA-ROMERO, A; MUÑOZ JIMÉNEZ, J. El paisaje en el ámbito de la geografia. México: Universidad Nacional Autónoma de México, Instituto de Geografía, 2002. (Série Temas selectos de geografía de México: métodos y técnicas para el estudio del território, III).

GEORGE, P. Os métodos da Geografia. Tradução de Heloysa de Lima Dantas. São Paulo: Difusão Européia do Livro, 1972.

GIL, A. C. Métodos e técnicas de pesquisa social. 6. ed. São Paulo: Atlas, 2008.

GOMES, P. C. C. O lugar do olhar: elementos para uma geografia da visibilidade. Rio de Janeiro: Bertrand Brasil, 2013.

GOOGLE. Google Earth PRO para computador. Versão 7.3. Nota (Fazenda Velha, Sete LagoasMinas Gerais). Disponível em: https://www.google.com/int//pt-BR ALL/earth/versions/\#download-pro. Acesso em: abr. 2020.

GURAN, M. Considerações sobre a constituição e a utilização de um corpus fotográfico na pesquisa antropológica. Discursos Fotográficos, Londrina, v. 7, n. 10, p. 77-106, 2011. https://doi.org/10.5433/1984-7939.2011v7n10p77

GUSMÃO, L. de. 0 fetichismo do conceito: limites do conhecimento teórico na investigação social. Rio de Janeiro: Toopbooks, 2012.

HEIDEGGER, M. Ser e tempo. 6. ed. Tradução de Mácia Sá C. Shuback. Petrópolis, RJ: Vozes; Bragança Paulista, SP: Editora Universitária São Francisco, 2012. 
IBGE - Instituto Brasileiro de Geografia e Estatística. Base de dados vetoriais da malha territorial brasileira (2010). Disponível em: https://www.ibge.gov.br/geociencias/downloads-geociencias.html. Acesso em: março de 2019.

KOZEL, S. Das imagens à linguagem do geográfico: Curitiba, a "capital ecológica". 2001. Tese (Doutorado) - Universidade de São Paulo, São Paulo, 2001.

KOZEL, S. Geopoética das paisagens: olhar sentir e ouvir a "natureza". Caderno de Geografia PUC Minas, Belo Horizonte, v. 22, n. 37, p. 65-78, 2012.

KOZEL, S. Mapas mentais: dialogismo e representações. Curitiba, PR: Appris, 2018.

LAKATOS, E. M. Fundamentos de metodologia científica. 7. ed. São Paulo: Atlas, 2010.

LAPLANTINE, F. A descrição etnográfica. Tradução de João Manuel Ribeiro Coelho e Sergio Coelho. São Paulo: Terceira Margem, 2004.

MARCONI, M. de A.; LAKATOS, E. M. Técnicas de pesquisa. 7. ed. São Paulo: Atlas, 2008.

MERLEAU-PONTY, M. Fenomenologia da percepção. São Paulo: Martins Fontes, 1999.

PEDROSA, B. V. O império da representação: a virada cultural e a Geografia. Espaço e Cultura, Rio de Janeiro: Uerj, n. 39, p. 31-58, 2016. https://doi.org/10.12957/espacoecultura.2016.31750

PEIRANO, M. Etnografia e rituais: relato de um percurso. Anuário Antropológico [on line], Brasilia, v. 1, 2016. Disponível em: <http://journais.openedition.org/aa/2011 DOI 10.400/aa.2011>. Acesso em: 29 out. 2019.

PETRONCELLI, E. II paesaggio: un tema transdiciplinare. Napoli: FedOAPress, 2019.

RAFFESTIN, C. Uma concepção de território, territorialidade e paisagem. In: PEREIRA, S. R.; COSTA, B. P.; SOUZA, E. B. C. (Org.). Teorias e práticas territoriais: análises espaço-temporais. São Paulo: Ed. Expressão Popular, 2010. p. 13-24.

RIOS, S. O.; COSTA, J. M. A.; MENDES, V. L. P. A fotografia como técnica e objeto de estudo na pesquisa qualitativa. Discursos Fotográficos, Londrina, v. 12, n. 20, p. 98-120, 2016. https://doi.org/10.5433/1984-7939.2016v12n20p98

SABBION, P. Paesaggio come esperienza. Firenzi: Franco Angeli, 2016.

SANTOS, M. A natureza do espaço: técnica e tempo: razão e emoção. São Paulo: Edusp, 1996.

SANTOS, M. Metamorfoses do espaço habitado. São Paulo: Hucitec, 1998.

SERPA, A. Por uma Geografia dos espaços vividos: Geografia e Fenomenologia. São Paulo: Contexto, 2019.

SILVA, L. de M. R. A "chancela de paisagem cultural brasileira" e sua contextualização no Vale do Jequitinhonha: a constituição identitário-regional da emergência quilombola e o patrimônio vivido do sítio histórico-geográfico de Alto dos Bois. 2019. Tese (Doutorado) - PPGEO, Instituto de Geociências, UFMG, Belo Horizonte, 2019.

SOUZA, M. L. de. Os conceitos fundamentais da pesquisa sócio-espacial. Rio de Janeiro: Bertrand Brasil, 2013.

SPINK, M. J; MENEGON, V. M; MEDRADO, B. Oficinas como estratégia de pesquisa: articulações teórico-metodológicas e aplicações ético-políticas. Psicologia \& Sociedade, [s.I.], v. 26, n. 1, p. 32-43, abr. 2014. https://doi.org/10.1590/S0102-71822014000100005

TUAN, Y.-F. Topofilia: um estudo da percepção, atitudes e valores do meio ambiente. São Paulo: Difel, 1980.

TURATO, E. R. Tratado da metodologia da pesquisa clínico-qualitativa. Petrópolis, RJ: Vozes, 2003. https://doi.org/10.1590/S0034-89102005000300025

TURATO, E. R. Métodos qualitativos e quantitativos na área da saúde: definições, diferenças e seus objetivos de pesquisa. Revista Saúde Pública, São Paulo, v. 39, n. 3, p. 507-516, 2005.

VARGAS, M. A. M. Desvelando heranças, tradições e práticas de jovens de Japaratuba, SE. Revista Cerrados, Montes Claros, MG: Unimontes, v. 15, p. 3-29, 2017. https://doi.org/10.22238/rc24482692v15n12017p03a29 
WEBER, F. Guia para a pesquisa de campo. Petrópolis, RJ: Vozes, 2000. https://doi.org/10.1590/S0104-71832009000200007

WEBER, F. A entrevista, a pesquisa e o íntimo, ou por que censurar seu diário de campo? Revista Horizontes Antropológicos, Porto Alegre, ano 15, n. 32, p. 157-170, jul.-dez. 2009.

WITAKER, D. Sociologia rural. Presidente Wenceslau, SP: Letras à Margem, 2002.

Recebido em: 22/11/2019

Aceito para publicação em: 08/06/2020 